\title{
Impact of Flood 2010 on the Fertility Status of Soil of Tehsil Garhi Khairo, District Jacobabad, Pakistan
}

\author{
Adnan Murad Bhayo ${ }^{1,2}$, Muhammad Latif ${ }^{2}$, Javed Ali Babar ${ }^{3}$, \\ Allah Wadhayo Gandahi
}

\author{
${ }^{1}$ H.E.J. Research Institute of Chemistry, International Center for Chemical and Biological Sciences \\ (ICCBS), University of Karachi, Karachi 75270, Pakistan. \\ ${ }^{2}$ Department of Chemistry, Federal Urdu University of Arts, Science and Technology, Karachi \\ 75270, Pakistan.
}

${ }^{3}$ Department of Soil Sciences, Sindh Agriculture University Tandojam, Tandojam 70060, Pakistan.

*Corresponding author's e-mail: adnan.murad@iccs.edu

Keywords: Flood 2010, soil, agriculture, crops, Jacobabad.

\begin{abstract}
A field study was carried out to assess some measurable changes in chemical properties of the soil of tehsil Garhi Khairo, district Jacobabad that was affected by 'Supra flood 2010'. Fortyfive composite soil samples were collected at sampling depths, 0-15 cm, 15-30 cm, and 30-45 cm from 15 different regions of tehsil Garhi Khairo before and after flood. Samples were analyzed for the determination of various chemical parameters such as $\mathrm{pH}$, electrical conductivity, soluble sodium $\left(\mathrm{Na}^{+}\right)$, potassium $\left(\mathrm{K}^{+}\right)$, calcium $\left(\mathrm{Ca}^{+2}\right)$, and magnesium $\left(\mathrm{Mg}^{+2}\right)$. Results of the analysis were compared with the reference data that were analyzed before the flood. Results of the analysis revealed that due to flood, chemical nature of soil was changed from slightly alkaline to strongly alkaline. Before and after flood soil remains non-saline. There has been a significant increase in the optimum concentration of soluble sodium $\left(\mathrm{Na}^{+}\right)$, calcium $\left(\mathrm{Ca}^{+2}\right)$ and magnesium $\left(\mathrm{Mg}^{+2}\right)$. However; potassium $\left(\mathrm{K}^{+}\right)$content of the soil was uniformly decreased.
\end{abstract}

\section{Introduction}

Flood is considered as a potential risk to lives, land, assets and ecosystem [3]. Pakistan has faced floods in 1950, 1956, 1957, 1973, 1976, 1978, 1992, and 2010. The flood 2010 was an extraordinary and unprecedented event in the known history of River Indus [14]. Since, Sindh province lies at the base of River Indus and is being almost flat consequentially the extra water in the form of rain or flood is crossing from it which is more often than the normal drain capacity. Left bank outfall drain (LBOD) has a release capacity of 4000 cusecs while the drain water discharges with the rate of 18000 cusecs, such addition water constrained the channels to overtop and break. It has been expected that flood 2010 had demonstrated to be more destroying particularly for the areas of upper Sindh, especially Jacobabad [12], [9].

In August 2010, two deadly and overwhelming rounds of monsoon rains had severely smashed the district by drowning them via affecting 197,320 peoples, causing around hundreds of human deaths and thousands of animal causalities. Peoples of this territory mainly depend on agriculture, livestock and fisheries. All of these divisions were massively crushed due to heavy rains that gave a financial loss of 160, 107 PKR millions and 4.5 million acres standing crops were destroyed. Losses caused by flood not constrained to only economic concern but these were expected to be long enduring in term of the destruction of natural resources including effecting the soil quality of the district [29], [10].

Usually, the agro-based economy relies more prominently on the fertility status of the soils of any area. The balance of nutrients in the soil is the key approach to enhance the yield of the crop. Overabundance and imbalanced status of nutrients due to flooding lead to cause nutrient mining from the soil, deteriorated the productivity of crops and eventually impact on the health of the soil [18], [21], [11]. 
This study was planned to evaluate the effect of flooding on the fertility status of soil. The information about status of nutrients in soil shall help in the selection of proper fertilizer to supply. Analysis of the chemical properties of soil is reported in a number of articles however no study has been published on the effect of flood water on the chemical properties of the soil of district Jacobabad, Pakistan.

\section{Description of study area}

Garhi Khairo is one of the Tehsil of Jacobabad district which is located on the border of Sindh and Balochistan province at latitude $28^{0} 16^{\prime} 37.32^{\prime}{ }^{\prime} \mathrm{N}$ and longitude $68^{\circ} 27^{\prime} 05.04^{\prime}$ 'E. Garhi khairo Tehsil is unique as the hottest spot in South Asia where the mercury in thermometer rises above $50^{\circ} \mathrm{C}$. Like other regions of province, this area is also deficient in rainfall. Due to shortage of water, artificial irrigation is the major resource to irrigate crops. Crops for instance rice, pulses, and vegetables like onion, tomato, and fruit trees like jujube are mainly growing throughout the Tehsil.

\section{Materials and Methods}

\section{Sampling of soil}

Soil samples collection was carried out in the rice farmland area of Goth Alahndo Jamali, tehsil Garhi Khairo, district Jacobabad, Sindh, Pakistan. Forty five samples before and after flood were collected at $0-15 \mathrm{~cm}, 15-30 \mathrm{~cm}$, and $30-45 \mathrm{~cm}$ from 15 different regions of tehsil Garhi Khairo, as to systematically investigate the effects of flood deeply in soil profile. Plants debris and stones were removed before taking samples. Samples were placed in clean polyethylene bags, which were labelled clearly. Analysis of soil samples before flood was carried out by Allah Wadhayo Gandahi and Javed Ali Babar in Department of Soil Sciences, Sindh Agriculture University Tandojam, while samples after flood was analysed by Adnan Murad Bhayo and Muhammad Latif in Department of Chemistry, Federal Urdu University of Arts, Science and Technology, Pakistan.

\section{Methods used for laboratory analysis}

Samples were air dried in the open air under shades, crushed, ground and passed through 1/8th inches mesh screen sieve. Samples were investigated for important chemical properties of soil including, $\mathrm{pH}$ and electrical conductivity (EC) using 1:5 soil water extract [20]. Calcium $\left(\mathrm{Ca}^{+2}\right)$ and magnesium $\left(\mathrm{Mg}^{+2}\right)$ were analyzed as proposed by [5]. Nutrient status categorization for sodium $\left(\mathrm{Na}^{+}\right)$and potassium $\left(\mathrm{K}^{+}\right)$were determined as reported by [19].

\section{pH:}

The availability of nutrients in soil is mainly dictated by Soil $\mathrm{pH}$.. The pre-flood obtained data is suggested that the $\mathrm{pH}$ of the soil of the area is generally slightly alkaline $(<8.0)$ in reaction while, it tuned to strongly highly alkaline nature $(>8.0)$ in almost all soil samples due to flood (Figure 1). Upon critical evaluation of data, it has been observed that the $\mathrm{pH}$ at all sites before the flood was in a range of 7.2-7.9 while after flood, $\mathrm{pH}$ was observed in the range of 8.1-9.2. The flooding and runoff from the upland may deposite layers of salts, hence an enhancement in $\mathrm{pH}$ is presumed from the outcomes [17]. These findings are in line with the research group of who revealed that the $\mathrm{pH}$ of the soil of rice cultivated area (after the flood) was alkaline in nature. It has been proved that the availability of toxic substances decreases with increasing $\mathrm{pH}$ of soil. 


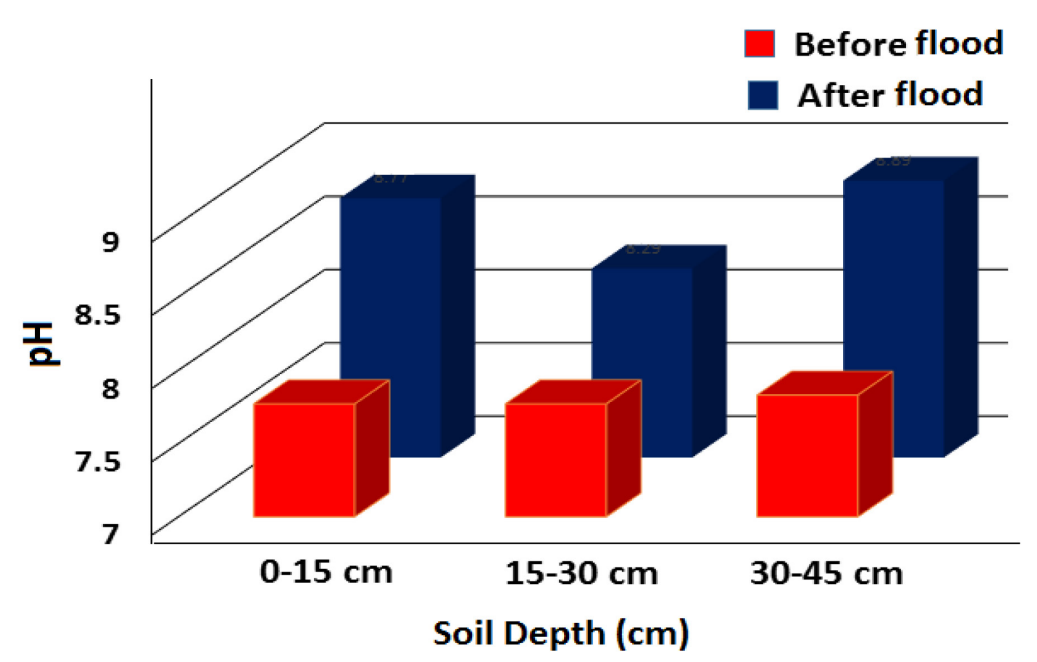

Figure 1. $\mathrm{pH}$ at three different depths of soil before and after the flood.

\section{Electrical conductivity (EC)}

Electrical conductivity (EC) is a measure of the extent of the current carrying ability of the analyte that gives a clear indication for the presence of soluble salts in the soil. EC values may influence by varying soil chemical properties such as, soil depth, salinity, porosity, and integrity of the presence of charge containing specie and their exchange capability [6], [23]. EC values of the sampled spots on three different soil layers are depicted in Figure 2. Average value of EC before flood at depth $0-15 \mathrm{~cm}, 15-30 \mathrm{~cm}, 30-45 \mathrm{~cm}$ are 1390,990 and $580 \mu \mathrm{s} / \mathrm{cm}$, respectively. While after flood average value of EC at depth $0-15 \mathrm{~cm}, 15-30 \mathrm{~cm}$, and $30-45 \mathrm{~cm}$ are 1470,1120 and $860 \mu \mathrm{s} / \mathrm{cm}$, respectively. This is due to the exogenous input of salts, ions and total dissolved solids carried by the flood from the ocean into the soil. EC values are in range of limit that are indicative of soils which have low salinity hazards to plants. These findings are in line with previous studies [16], [4].

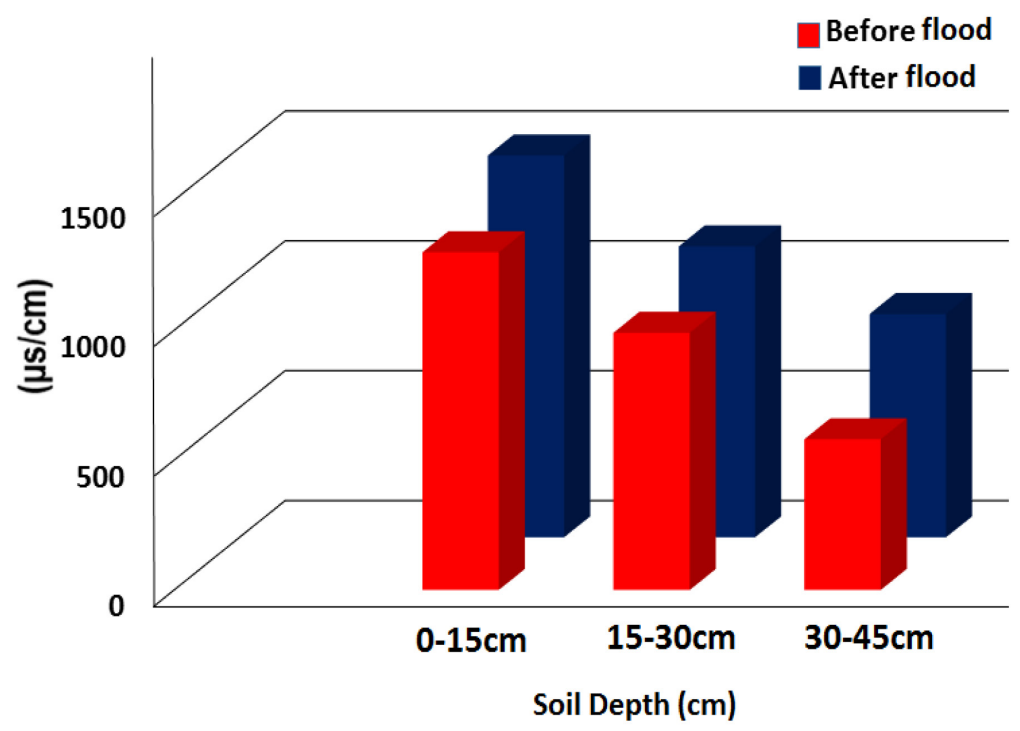

Figure 2. EC at three different depths of soil before and after the flood.

\section{Sodium $\left(\mathrm{Na}^{+}\right)$}

Sodium helps plants in synthesis of chlorophyll and metabolic process. The Optimum value of sodium in agricultural soil for fertile soil should be in between 120-180 ppm [24], [15]. The content of sodium in reference spots was in a range of 52-208 ppm while, it ranged from 90-153 ppm after flood (Figure 3). The enhancement of sodium at depth $30-45 \mathrm{~cm}$ due to leaching and dilution because flooding increases the solubility of mineral nutrients. Increment in basic salt deposition in soil is also proved through $\mathrm{pH}$ and Electrical conductivity value. In practical terms, extreme 
alkaline $\mathrm{pH}$ due to soluble sodium $\left(\mathrm{Na}^{+}\right)$in soil lead to nutrient imbalances in the roots of plants [8], [28]. More ever, before flood the maximum value of soluble sodium (116 ppm) was observed at depth $0-15 \mathrm{~cm}$ and minimum value of soluble sodium $(22 \mathrm{ppm})$ was observed at depth $30-45 \mathrm{~cm}$. While after flood both maximum (325 ppm) and minimum value $(10 \mathrm{ppm})$ of soluble sodium was noted at depth $0-15 \mathrm{~cm}$. Such results were also observed in previous research [25].

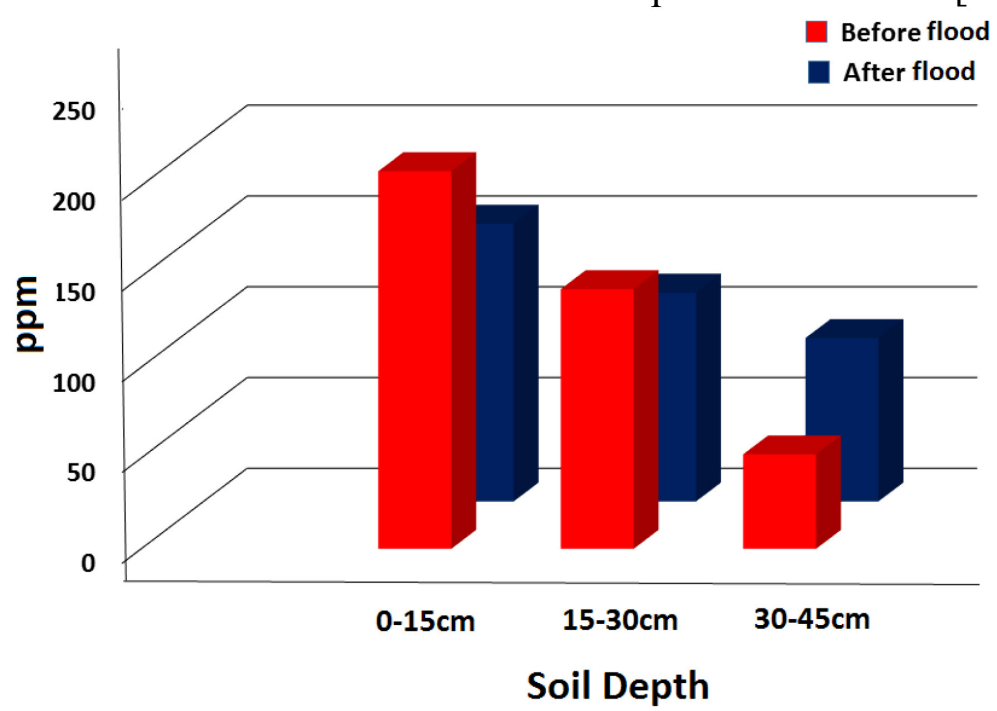

Figure 3. $\mathrm{Na}^{+}$at three different depths of soil before and after the flood

\section{Potassium $\left(\mathbf{K}^{+}\right)$}

Potassium is crucial in almost all biological processes necessary to withstand plant life and catalyze important metabolic reactions, such as photosynthesis, regulation of nutrients and water intake [27]. On the basis of concentration of potassium, soil categorized as very low $(<5 \mathrm{ppm})$, low (5-8 ppm), optimum $(8-17 \mathrm{ppm})$ and high $(17-30 \mathrm{ppm})$. Soil test potassium at different soil depths are given in Figure 4. The results of the study revealed that the potassium content of the sampled sites was generally high $(>30 \mathrm{ppm})$ in all samples with no systematic trend. Before flood $84.21 \%$ soil samples at depth $0-15 \mathrm{~cm}, 73.68 \%$ samples at depth $30-45 \mathrm{~cm}$ and $58.42 \%$ soil samples at $30-$ $45 \mathrm{~cm}$ soil depth were high in soluble potassium. After flood $33 \%$ soil sample at $0-15 \mathrm{~cm}, 13.33 \%$ at depth $15-30 \mathrm{~cm}$ and and $0.00 \%$ soil samples at $30-45 \mathrm{~cm}$ soil depth were in the category of high in soluble potassium. On overall basis the potassium content was in a range of 16 to $25 \mathrm{ppm}$. Decrease in potassium content of soil after flood is also proved from previous study [22].

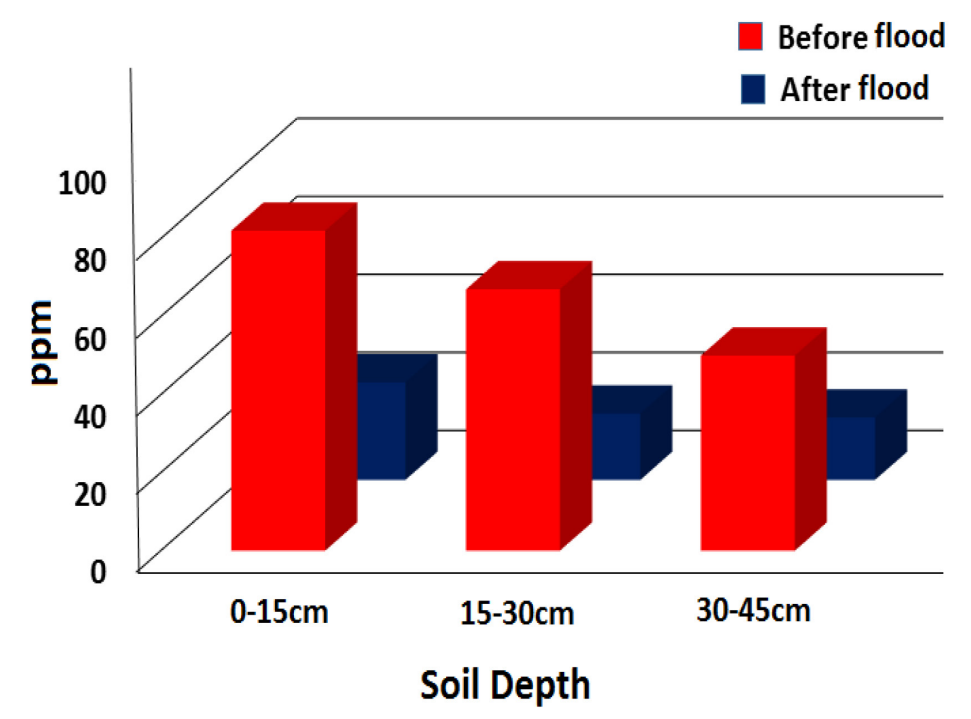

Figure 4. $\mathrm{K}^{+}$at three different depths of soil before and after the flood 


\section{Magnesium $\left(\mathrm{Mg}^{+2}\right)$}

Magnesium is known for its important role in photosynthesis, as it is considered as a building block of the chlorophyll that enables leaves to appear green [13]. On the basis of concentration of magnesium, soil categorized as low (12.2 ppm), optimum (12.2-122 ppm) and high (>122 ppm). Before flood 5.26, 89.47, 5.26\% at depth $0-15 \mathrm{~cm}, 36.84,63.15,00 \%$ at depth $15-30 \mathrm{~cm}$ and 68.42 , $31.57,00 \%$ samples at depth $30-45 \mathrm{~cm}$ were low, optimum and high in magnesium concentration, respectively. After flood 6.66, 13.33, 80\% at depth $0-15 \mathrm{~cm}, 00,26.66,73.33 \%$ at depth $15-30 \mathrm{~cm}$ and $00,53.33,46.66 \%$ samples at depth $30-45 \mathrm{~cm}$ were low, optimum and high in magnesium concentration, respectively Figure 5. Increase in magnesium concentration sharply observed in all of three depths. These observations are in line with previous research [1].

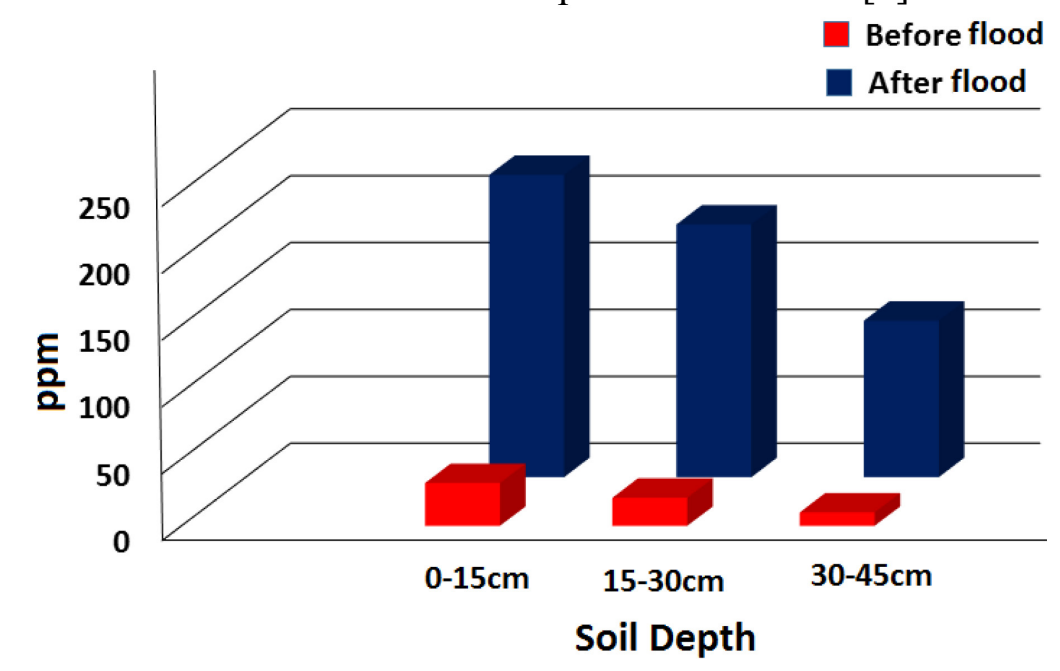

Figure 5. $\mathrm{Mg}^{+}$at three different depths of soil before and after the flood

\section{Calcium $\left(\mathrm{Ca}^{+2}\right)$}

Calcium helps to maintain chemical balance in the soil, reduces soil salinity, and improves water penetration [7]. On the basis of concentration of calcium in soil, soil categorized as low $(>80 \mathrm{ppm})$ optimum $(80-400 \mathrm{ppm})$ and high $(<400 \mathrm{ppm})$ in calcium concentration. Before flood $72 \%$ and $28 \%$ soils at $0-15 \mathrm{~cm}, 88$ and $12 \%$ soil samples at $15-30 \mathrm{~cm}$ and 100 and zero \% soil samples at $30-45 \mathrm{~cm}$ soil depth were low and optimum in soluble calcium, respectively. While after flood, all samples that were analyzed were in optimum soluble calcium level, respectively (Figure 6). It was indicated that the soil of Tehsil changed from low to optimum calcium content category. Such outcomes were also observed in other research [18]. 


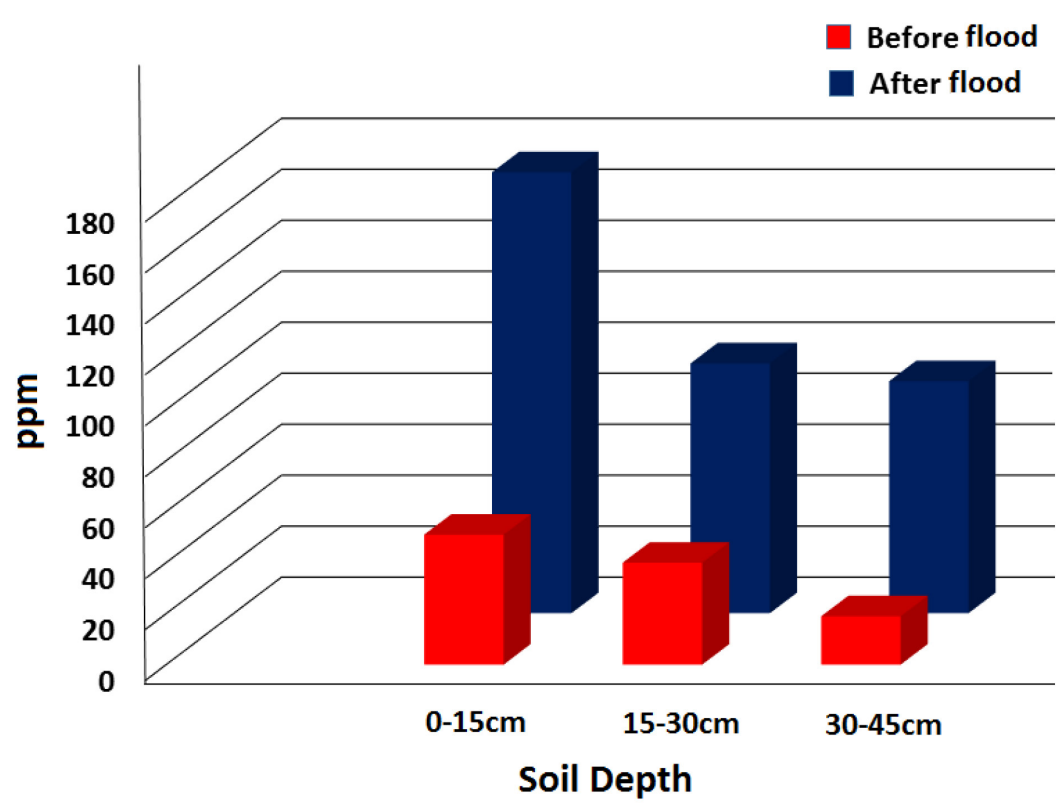

Figure 6. $\mathrm{Ca}^{+2}$ at three different depths of soil before and after the flood

Table 1. Comparison of data before and after flood

\begin{tabular}{|c|c|c|c|c|c|}
\hline Parameters & $\begin{array}{c}\text { Depth } \\
\text { (cm) }\end{array}$ & Before Flood & $\begin{array}{c}\text { Category } \\
\text { (overall) }\end{array}$ & After Flood & $\begin{array}{c}\text { Category } \\
\text { (overall) }\end{array}$ \\
\hline \multirow{3}{*}{$\mathbf{p H}$} & $0-15$ & 7.77 & \multirow{3}{*}{$\begin{array}{l}\text { SLIGHTLY } \\
\text { ALKALINE }\end{array}$} & 8.77 & \multirow{3}{*}{$\begin{array}{l}\text { STRONGLY } \\
\text { ALKALINE }\end{array}$} \\
\hline & $15-30$ & 7.77 & & 8.29 & \\
\hline & $30-45$ & 7.83 & & 8.89 & \\
\hline \multirow{3}{*}{$\begin{array}{c}\text { Electrical } \\
\text { conductivity } \\
(\mu \mathrm{s} / \mathrm{cm})\end{array}$} & $0-15$ & 1300 & \multirow{3}{*}{$\begin{array}{c}\text { NON } \\
\text { SALINE }\end{array}$} & 1470 & \multirow{3}{*}{$\begin{array}{c}\text { NON } \\
\text { SALINE }\end{array}$} \\
\hline & $15-30$ & 990 & & 1120 & \\
\hline & $30-45$ & 580 & & 860 & \\
\hline \multirow{3}{*}{$\begin{array}{l}\text { Sodium } \\
\text { (ppm) }\end{array}$} & $0-15$ & 208 & \multirow{3}{*}{ OPTIMUM } & 153 & \multirow{3}{*}{ OPTIMUM } \\
\hline & $15-30$ & 143 & & 115 & \\
\hline & $30-45$ & 52 & & 90 & \\
\hline \multirow{3}{*}{$\begin{array}{c}\text { Potassium } \\
(\mathrm{ppm})\end{array}$} & $0-15$ & 82 & \multirow{3}{*}{$\begin{array}{l}\text { VERY } \\
\text { HIGH }\end{array}$} & 25 & \multirow{3}{*}{ OPTIMUM } \\
\hline & $15-30$ & 67 & & 17 & \\
\hline & $30-45$ & 50 & & 16 & \\
\hline \multirow{3}{*}{$\begin{array}{c}\text { Calcium } \\
\text { (ppm) }\end{array}$} & $0-15$ & 51 & \multirow{3}{*}{ LOW } & 173 & \multirow{3}{*}{ OPTIMUM } \\
\hline & $15-30$ & 40 & & 98 & \\
\hline & $30-45$ & 19 & & 91 & \\
\hline \multirow{3}{*}{$\begin{array}{l}\text { Magnesium } \\
\text { (ppm) }\end{array}$} & $0-15$ & 32 & \multirow{3}{*}{ OPTIMUM } & 226 & \multirow{3}{*}{ HIGH } \\
\hline & $15-30$ & 21 & & 189 & \\
\hline & $30-45$ & 10 & & 117 & \\
\hline
\end{tabular}

\section{Conclusion}

From the whole study, it can be concluded that flood has both beneficial and harmful effects on soil and ground water. Beneficial effect in the sense that, after flood calcium and potassium concentration changed from low to optimum level. Disadvantage in the sense that magnesium concentration increased much more after flood and reaches at hazardous level. The information of soils related to the status of nutrients shall help in selection of proper nutrients to supply. 


\section{Conflict of Interest}

The authors declare that there is no conflict of interest.

\section{References}

[1] W. Bednarek et al., Physicochemical properties of surface soil layer after the flood in the middle Vistula River Valley, Journal of Elementology. 19(1) (2014).

[2] P. Bhattacharya et al., Metal contamination at a wood preservation site: characterisation and experimental studies on remediation, Science of the Total Environment. 290(1-3) (2002) 165180.

[3] B. Carroll et al., Health and social impacts of a flood disaster: responding to needs and implications for practice, Disasters. 34(4) (2010) 1045-1063.

[4] E.J. Chaneton, R.S. Lavado, Soil nutrients and salinity after long-term grazing exclusion in a Flooding Pampa grassland, Journal of Range Management. (1996) 182-187.

[5] K.L. Cheng, R.H. Bray, Determination of calcium and magnesium in soil and plant material, Soil Science. 72(6) (1951) 449-458.

[6] D. Corwin, S. Lesch, Application of soil electrical conductivity to precision agriculture, Agronomy Journal. 95(3) (2003) 455-471.

[7] E. Epstein, The essential role of calcium in selective cation transport by plant cells, Plant Physiology. 36(4) (1961) 437.

[8] C.D. Foy, Soil chemical factors limiting plant root growth. Limitations to plant root growth, Springer, 1992, pp. 97-149.

[9] K. Gaurav et al., The Indus flood of 2010 in Pakistan: a perspective analysis using remote sensing data, Natural Hazards. 59(3) (2011) 1815.

[10] H.N. Hashmi et al., A critical analysis of 2010 floods in Pakistan, African Journal of Agricultural Research. 7(7) (2012) 1054-1067.

[11] M.B. Jackson, The impact of flooding stress on plants and crops. Available at: http://www.plantstress.com/Articles/. [Accessed July 2018].

[12] A. Khan et al., Rapid assessment of flood impact on the environment in selected affected areas of Pakistan, Pakistan Wetlands Programme and UNDP Pakistan, 2010, 35.

[13] E. Kirkby, K. Mengel, The role of magnesium in plant nutrition, Zeitschrift für Pflanzenernährung und Bodenkunde. 139(2) (1976) 209-222.

[14] T.D. Kirsch et al., Impact of the 2010 Pakistan floods on rural and urban populations at six months, PLoS currents. 4 (2012).

[15] H. J. Kronzucker et al., Sodium as nutrient and toxicant, Plant and Soil. 369(1-2) (2013) 1-23.

[16] C. Neill, Seasonal flooding, soil salinity and primary production in northern prairie marshes, Oecologia. 95(4) (1993) 499-505.

[17] M. Olomu et al., Effect of Flooding on the Eh, pH, and Concentrations of Fe and $\mathrm{Mn}$ in Several Manitoba Soils 1, Soil Science Society of America Journal. 37(2) (1973) 220-224.

[18] F. Ponnamperuma, Effects of flooding on soils, Flooding and plant growth. (1984) 9-45. 
[19] E. C. Proehl, W. P. Nelson, The flame photometer in determination of sodium and potassium, American Journal of Clinical Pathology. 20(9) (1950) 806-813.

[20] D.L. Rowell, The preparation of saturation extracts and the analysis of soil salinity and sodicity, Soil Science Methods and Applications, UK: Longman Group, 1994.

[21] K. Sahrawat, Flooding soil: a great equalizer of diversity in soil chemical fertility, Oryza. 35 (1998) 300-305.

[22] N. Slaton et al., Potassium nutrition of flood-irrigated rice, Better crops. 88(3) (2004) 20-22.

[23] A. Stadler et al., Quantifying the effects of soil variability on crop growth using apparent soil electrical conductivity measurements, European journal of agronomy. 64 (2015) 8-20.

[24] G. Subbarao et al., Sodium - a functional plant nutrient, Critical Reviews in Plant Sciences. 22(5) (2003) 391-416.

[25] A. Swarup, Effect of flooding on physico-chemical changes in sodic soils, Zeitschrift für Pflanzenernährung und Bodenkunde. 144(2) (1981) 136-142.

[26] E. Visser et al., Flooding and plant growth, Annals of Botany. 91(2) (2003) 107-109.

[27] A.J. Walter, C.D. Difonzo, Soil potassium deficiency affects soybean phloem nitrogen and soybean aphid populations, Environmental Entomology. 36(1) (2014) 26-33.

[28] N.J. Warrence et al., Salinity, sodicity and flooding tolerance of selected plant species of the northern Cheyenne Reservation, Montana State University Extension Water Quality Program, 2001.

[29] P. Webster et al., Were the 2010 Pakistan floods predictable?, Geophysical research letters 38(4) (2011). 